\title{
Storage Life of Illinois Bundleflower and Western Indigo Seed
}

\author{
C.A. CALL
}

\begin{abstract}
Seed of Illinois bundleflower (Desmanthus illinoensis (Michs.) MacM.) and western indigo (Indigofera miniata var. leptosepala ( relative humidity were imbibed in a controlled environment for 20 Turdays with a night/day temperature regime of $15 / 25^{\circ} \mathrm{C}$ and a 12-hour en stored for 1 to 4 years at $16^{\circ} C$ and $40 \%$ photoperiod. Preimbibition treatments included acid scar-ification by immersion in concentrated sulfuric acid for 15 minutes, mechanical scarification by cutting the seed coat at the end opposite the micropyle, and an untreated control. Seed viability was determined by a triphenyl tetrazolium chloride test. Germination rate and cumulative germination decreased for untreated Illinois bundleflower seed and increased for untreated western indigo seed as the length of storage increased from 1 to 4 years. The decrease in germinability of Illinois bundleflower seed was related to the development of an impermeable seed coat, while the increase in germinability of western indigo seed was related to a decease in hard seededness and the fulfilment of after-ripening requirements. Scarification treatments increased cumulative germination and germination rates in each seed storage class for both species. Over the 4-year storage period, Illinois bundleflower seed viability decreased by approximately $10 \%$, and western indigo viability remained relatively constant.
\end{abstract}

Native legumes are either nonexistent or make minor contributions on millions of hectares of rangeland in the southern Great Plains because of selective removal by past grazing (Sims et al. 1980). Few native legumes are being used in rangeland plantings even though they have a high forage quality and are a potential source of economical nitrogen for increasing the productivity of native and introduced grass plantings. However, several native legumes, including Illinois bundleflower (Desmanthus illinoensis (Michs.) MacM.) and western indigo (Indigofera miniata var. leptosepala (Nutt.) Turner), are being evaluated for range improvement uses by the Soil Conservation Service (SCS) in cooperation with the Texas Agricultural Experiment Station and the Texas Parks and Wildlife Department (Soil Conservation Service 1980).

Illinois bundleflower, a deep-rooted, warm-season, perennial legume, is widely but sparsely distributed throughout the prairies

\footnotetext{
Author is assistant professor, Range Science Department, Texas A\&M University, College Station 77843. The author gratefully acknowledges the SCS Plant Materials Center, Knox City, Texas, for providing seeds used in this study, and Matthew Wagner and Lee Sumrall for their assistance in germination evaluation.

Published with the approval of the Director, Texas Agricultural Experiment Station as TA-20320.

Manuscript accepted March 13, 1985.
}

and plains in the midwestern and southwestern U.S. (Latting 1961). 'Sabine' Illinois bundleflower, recently released by the SCS Plant Materials Center at Knox City, Texas, appears best adapted to areas in Texas and Okla homa, receiving $50 \mathrm{~cm}$ or greater mean annual precipitation (Soil Conservation Service 1983). Plants grow on a wide variety of soils, except coarse sands and dense clays (Wasser 1982). Western indigo, a deep-rooted, mat-forming, coolseason, perennial legume, occurs in the eastern two-thirds of Texas and Oklahoma (Graham 1941, Soil Conservation Service 1980). Both species are palatable to all classes of livestock and are used by wildlife for food and cover (Rechenthin 1972, Wasser 1982).

Illinois bundleflower and western indigo have the potential to be used in seeding mixtures for revegetation of disturbed and deteriorated rangelands in Texas and Oklahoma. However, as with many native forb species, we are lacking information relative to the longevity and germinability of stored seeds (Hanelt 1977). Seed of many native forb species used in rangeland revegetation programs is available only from wildland sources and/or a limited number of commercial growers. Unfavorable environmental conditions during flowering or seed development periods may prevent yearly production of good seed crops (Mayer and Poljakoff-Mayber 1982, Stevens et al. 1981). Therefore, seed may need to be stored under controlled conditions to have an adequate amount available for future plantings. The objective of this study was to evaluate the effects of short-term storage ( 1 to 4 years) on the germinability and viability of Illinois bundleflower and western indigo seed.

\section{Materials and Methods}

Seed of Sabine Illinois bundleflower and accession PMT-1051 of western indigo were obtained from the SCS Plant Materials center, Knox City, Texas. Seed of Illinois bundleflower had been collected in 1978,1979, 1980, and 1981; and seed of western indigo had been collected in 1978, 1980, and 1981. All seed had been stored at $16^{\circ} \mathrm{C}$ and $40 \%$ relative humidity prior to germination trials which took place from July to December, 1982. Seed collected in 1981, 1980,1979, and 1978 were respectively designated 1-year-old, 2-year-old, 3-year-old and 4-year-old seed in terms of storage age class.

Seed viability was determined by a triphenyl tetrazolium chloride (TTC) test (Grabe 1970). Three replicates of 50 undamaged seed from each storage age class for each species, preconditioned by cutting the seed coat with a razor blade at the end opposite the micropyle, were placed in a $0.03 \mathrm{M}$ solution of TTC in phosphate 
buffer $\left(0.06 \mathrm{M} \mathrm{KH}_{2} \mathrm{PO}_{4}-0.6 \mathrm{M} \mathrm{Na}_{2} \mathrm{HPO}_{4}\right)$ solution for 24 hours at $25^{\circ} \mathrm{C}$ in complete darkness. Percent viability was determined by evaluating intensity of staining and staining patterns under a $10 \mathrm{x}$ lens.

Germination trials were conducted with undamaged seeds from each storage age class. Pre-imbibition seed treatments included acid scarification, mechanical scarification, and an untreated control. Acid scarified seeds were immersed in $17.8 \mathrm{M} \mathrm{H}_{2} \mathrm{SO}_{4}$ for 15 minutes with continuous stirring and rinsed 3 times in distilled water. Seeds were mechanically scarified by cutting the seed coat with a razor blade at the end opposite the micropyle (Latting 1961). Due to a small number of seed, western indigo seeds did not undergo mechanical scarification.

Groups of 100 seeds each were dusted with captan (Cis-N((trichloromethyl)) thio) - 4 cyclohexene - 1,2 - dicarbocimide) fungicide and placed on a single piece of Whatman No. 1 chromatography paper in 13 by 13.5 by $3.5-\mathrm{cm}$ plastic trays. The paper was supported by a $5-\mathrm{mm}$ thick polyurethane foam pad with 5 cotton wicks which extended into a $200-\mathrm{ml}$ reservoir of distilled water (Berkat and Briske 1982).

Germination trials were conducted in a controlled environment chamber with a night/day temperature regime of $15 / 25^{\circ} \mathrm{C}$ and a 12-hour photoperiod. A light intensity of $450 \mu \mathrm{mol}^{-2} \mathrm{esec}^{-1}$ (photosynthetically active solar radiation) was maintained during the high temperature period. An alternating temperature regime of $15 / 25^{\circ} \mathrm{C}$ was selected for both species on the basis of previous germination studies which indicated that germination was greater at $15 / 25^{\circ} \mathrm{C}$ than alternating temperature regimes of $10 / 20$ and $20 / 30^{\circ} \mathrm{C}$ (C.A. Call, unpublished data; Kissock and Haferkamp 1983). A seed was considered to have germinated when it had at least 1 cotyledon exposed and radicle greater than or equal to $5 \mathrm{~mm}$ in length (Crosier 1970). Germinated seeds were counted and removed from trays every other day over a 20-day period, and cumulative germination data were reported as a percentage of the total number of seeds in each tray. Germination rates were estimated by calculating the mean time in days taken for nondormant viable seeds to germinate (Ellis and Roberts 1978). The mean germination time (MGT) was calculated as follows:

$$
\text { MGT }=\frac{\Sigma(D n)}{\Sigma n}
$$

Where $\mathbf{n}$ is the number of seeds which germinate on day $D$, and $D$ is the number of days counted from the beginning of the germination test.

Trays were arranged in a completely randomized design with 3 replications per seed treatment for each storage age. Analysis of variance and Duncan's multiple range test were utilized in data interpretation (Ray 1982). Cumulative germination data and viability data were transformed prior to analysis using an arcsine transformation (Steele and Torrie 1960).

\section{Results and Discussion}

\section{Illinois Bundleflower}

Under storage conditions of $16^{\circ} \mathrm{C}$ and $40 \%$ relative humidity, cumulative germination of untreated Illinois bundleflower seed decreased significantly $(P<0.05)$ as the length of the seed storage period increased from 1 to 4 years (Table 1). The germinability of untreated 4-year-old seed was less than one-half that of untreated 1-year-old seed. The germinability of untreated Illinois bundleflower seed has also been shown to decline after 4 months of storage at room temperature (Latting 1961). Latting (1961) related the reduction in germination to the rapid development of an impermeable seed coat following maturity.

Breaking the seed coat by mechanical scarification or weakening the seed coat by acid scarification significantly $(P<0.05)$ increased cumulative germination in each seed storage age class (Table 1). Mechanical scarification increased germination more effectively than acid scarification. The difference in germination between
Table 1. Cumulative germination of Sabine Illinois bundleflower seed as infuenced by length of seed storage period and a seed coat scarification treatment.

\begin{tabular}{lccc}
\hline $\begin{array}{l}\text { Year of } \\
\text { collection }\end{array}$ & $\begin{array}{c}\text { Storage period } \\
\text { (years) }\end{array}$ & $\begin{array}{c}\text { Scarification } \\
\text { treatment }\end{array}$ & $\begin{array}{c}\text { Germination } \\
(\%)\end{array}$ \\
\hline 1981 & 1 & untreated & $43 \mathrm{c}$ \\
& & acid & $82 \mathrm{~b}$ \\
& & mechanical & $96 \mathrm{a}$ \\
1980 & 2 & untreated & $28 \mathrm{~d}$ \\
& & acid & $67 \mathrm{c}$ \\
& & mechanical & $80 \mathrm{~b}$ \\
1979 & 3 & untreated & $29 \mathrm{~d}$ \\
& & acid & $84 \mathrm{~b}$ \\
1978 & 4 & mechanical & $94 \mathrm{a}$ \\
& & untreated & $20 \mathrm{e}$ \\
& & acid & $71 \mathrm{c}$ \\
\hline
\end{tabular}

'Means followed by the same letter are not significantly different at the 0.05 level according to Duncan's Multiple Range Test.

mechanically scarified seed and untreated seed indicated that the decrease in germination over time was due primarily to hard seededness, and not a loss of viability, since germination percentages of mechanically scarified seed were similar to viability percentages of seed scarified in the same manner prior to TTC testing. Seed viability was estimated at $97,82,94$, and $86 \%$, respectively, for 1-, 2-, 3-, and 4-year-old seed. Seed viability decreased by $11 \%$ over the 4-year storage period.

Cumulative germination data and viability data for seed collected in 1980 and stored for 2 years do not conform to the general trends that developed for the other seed storage age classes over the 4-year period (Table 1). Cumulative germination for untreated 2-year-old seed was slightly lower than that for untreated 3-yearold seed. Acid-scarified and mechanically-scarified 2-year-old seed had significantly $(P<0.05)$ lower germination than similarly treated 3-year-old seed, and slightly lower germination than similarly treated 4-year-old seed. The viability of 2-year-old seed was significantly $(P<0.05)$ lower than that of 3 -year-old seed, and slightly lower than that of 4-year-old seed.

Seed viability and germinability are not only a function of seed storage, but also the environmental conditions to which the parent plant is exposed during seed formation and ripening (Mayer and Poljakoff-Mayber 1982). A heat stress during the seed maturation period, especially during the first part of the maturation period, can have marked effects on germinability (Koller 1972). Illinois bundleflower typically flowers in late May or early June and produces seed from mid-June to early July at the SCS Plant Materials Center at Knox City (personal communication, J.B. Muncreif, SCS, Knox City, Texas). During this 3-week period in 1980 , the daily maximum temperature was between 40 and $45^{\circ} \mathrm{C}$ for 13 days and above $45^{\circ} \mathrm{C}$ for 2 days as compared to 1978 with 2 days between 40 and $45^{\circ} \mathrm{C}$, and 1979 and 1981 with no days above $40^{\circ} \mathrm{C}$ (unpublished climatic data, SCS, Knox City, Texas). Even though the parent plants received supplemental irrigation to insure seed production, the higher temperature in 1980 would have increased transpirational losses and raised leaf, stem, and seed pod temperatures. Associated changes in parent plant metabolism could have had negative effects on seed development and subsequent germination and viability of stored seed.

Mean germination time, a measure of the germination rate of viable seeds, increased significantly for untreated seeds as the length of the storage period increased to 3 and 4 years (Table 2). Untreated, 4-year-old seed had an MGT of almost 2 days longer than 1-year-old seed. Germination rates in all seed storage age classes were accelerated when seed coats were weakened by acid 
Table 2. Mean germination time of Sabine Illinois bundleflower seed as influenced by length of seed storage period and seed coat scarification treatment.

\begin{tabular}{lccc}
\hline \hline $\begin{array}{l}\text { Year of } \\
\text { collection }\end{array}$ & $\begin{array}{c}\text { Storage period } \\
\text { (years) }\end{array}$ & $\begin{array}{c}\text { Scarification } \\
\text { treatment }\end{array}$ & $\begin{array}{c}\text { Mean } \\
\text { germination' } \\
\text { time (days) }\end{array}$ \\
\hline 1981 & 1 & $\begin{array}{c}\text { untreated } \\
\text { acid } \\
\text { mechanical }\end{array}$ & $\begin{array}{l}5.8 \mathrm{bc} \\
5.2 \mathrm{cde} \\
4.6 \mathrm{de}\end{array}$ \\
1980 & 2 & $\begin{array}{c}\text { untreated } \\
\text { acid }\end{array}$ & $5.9 \mathrm{bc}$ \\
& & mechanical & $5.5 \mathrm{bc}$ \\
1979 & 3 & untreated & $7.1 \mathrm{cde}$ \\
& & acid & $5.4 \mathrm{bcd}$ \\
1978 & & mechanical & $4.6 \mathrm{e}$ \\
& 4 & untreated & $7.6 \mathrm{a}$ \\
& & acid & $6.0 \mathrm{~b}$ \\
& & mechanical & $5.4 \mathrm{bcd}$ \\
\hline
\end{tabular}

${ }^{1}$ Means followed by the same letter are not significantly different at the 0.05 level according to Duncan's Multiple Range Test.

scarification or broken by mechanical scarification (Table 2). Significant $(P<0.05)$ decreases in MGT, by as much as 2.4 days, were noted for mechanically scarified 3-and 4-year-old seed. The rate of germination can be a critical factor in the success or failure of a wildland seeding, especially when germination occurs under transiently favorable water conditions (Hillel 1972, McDonough 1977).

\section{Western Indigo}

Cumulative germination of untreated western indigo seed increased significantly $(P<0.05)$ as the length of the seed storage period increased from 1 to 4 years (Table 3). Germination of

Table 3. Cumulative germination of western indigo seed as influenced by length of seed stonge period and seed coat scarification treatment.

\begin{tabular}{lccc}
\hline \hline $\begin{array}{l}\text { Year of } \\
\text { collection }\end{array}$ & $\begin{array}{c}\text { Storage period } \\
\text { (years) }\end{array}$ & $\begin{array}{c}\text { Scarification } \\
\text { treatment }\end{array}$ & $\begin{array}{c}\text { Germination! } \\
(\%)\end{array}$ \\
\hline 1981 & 1 & $\begin{array}{c}\text { untreated } \\
\text { acid }\end{array}$ & $\begin{array}{c}36 \mathrm{e} \\
77 \mathrm{~b}\end{array}$ \\
1979 & 2 & untreated & $48 \mathrm{~d}$ \\
& & acid & $80 \mathrm{ab}$ \\
1978 & 4 & untreated & $61 \mathrm{c}$ \\
& & acid & $86 \mathrm{a}$
\end{tabular}

${ }^{1}$ Means followed by the same letter are not significantly different at the 0.05 level according to Duncan's Multiple Range Test.

untreated 4-year-old seed was almost twice that of untreated 1year-old seed. This increase in germination with increasing storage time can be related to a decrease in hard seededness. Differences between acid scarified seed and untreated seed indicated that there were $42 \%, 32 \%$, and $25 \%$ hard seed, respectively, from the $1-, 2-$, and 4-year-old seed storage age classes (Table 3).

The increase in germinability may also be related to the fulfillment of after-ripening requirements during storage. Seed viability remained fairly constant over the 4-year storage period $(92,89$, and $90 \%$, respectively, for 1-, 2-, and 4-year-old seed), while germination of acid-scarified seed increased by $9 \%$ over the same period (Table 3). No anatomical or morphological differences were observed in seeds from different storage age classes. Therefore, it was assumed that the process of after-ripening was the result of chemical or physical changes in the seed or seed coat (i.e., an alteration of the composition of storage materials in the seed, a change in seed coat permeability, and/or the appearance of promoting substances or disappearance of inhibitory substances)
(Copeland 1976). These changes usually result in a gradual relaxation in the degree of strictness of the environmental requirements for germination (Koller 1972).

Germinability did not decline in seed collected in 1980 and stored for 2 years as it did with Illinois bundleflower. Western indigo typically flowers from April through September, and produces the majority of its seed earlier in the season than Illinois bundleflower (Rechenthin 1972). The seed development period apparently was not adversely affected by above-normal high temperatures in June and July 1980 as it may have been for Illinois bundleflower.

Mean germination time decreased slightly for untreated seeds as the length of the storage period increased from 1 to 4 years (Table 4). Significant $(P<0.05)$ decreases in MGT, by as much as 1.6 days, were observed for acid-scarified seed in all storage age classes.

Table 4. Mean germination time of western indigo seed as influenced by length of seed storage period and seed coat scarification treatment.

\begin{tabular}{lccc}
\hline \hline $\begin{array}{l}\text { Year of } \\
\text { collection }\end{array}$ & $\begin{array}{c}\text { Storage period } \\
\text { (years) }\end{array}$ & $\begin{array}{c}\text { Scarification } \\
\text { treatment }\end{array}$ & $\begin{array}{c}\text { Mean' } \\
\text { germination } \\
\text { time (days) }\end{array}$ \\
\hline 1981 & 1 & $\begin{array}{c}\text { untreated } \\
\text { acid }\end{array}$ & $\begin{array}{c}9.1 \mathrm{a} \\
7.5 \mathrm{~b}\end{array}$ \\
1980 & 2 & untreated & $8.7 \mathrm{a}$ \\
1978 & 4 & acid & $7.2 \mathrm{~b}$ \\
& & untreated & $8.6 \mathrm{a}$ \\
& & acid & $7.0 \mathrm{~b}$ \\
\hline
\end{tabular}

'Means followed by the same letter are not significantly different at the 0.05 level according to Duncan's Multiple Range Test.

Although there is no doubt that an increase in water permeability is an essential part of the dormancy-breaking action of a scarification treatment, it is by no means certain that this is the only result of this treatment (Mayer and Poljakoff-Mayber 1982). Physical and/or chemical changes in the seed coat may also result in associated changes in gas exchange permeability, and light and temperature response.

\section{Management Implications}

Various mechanisms regulate the germination of seeds in their natural habitat and determine whether a given seed will germinate in a certain environment. Dormancy in seeds (hard seededness or an immature embryo or a combination of the two) leads to the accumulation of individuals in a persistent seedbank, which acts as a mechanism to increase the genetic base of a population by mixing cohorts from one year with another (Thompson 1981). Seeds produced by the same population of plants over several years may show considerable differences in response to environmental factors such as light, temperature, and moisture (Grime 1979). Such a regenerative strategy protects native species from eradication as a result of adverse environmental conditions which may follow germination.

Revegetation seedings on wildlands should simulate the seedbank concept to a certain extent. The germinability of the selected species should be high enough to allow for the establishment of an acceptable stand during the first season, but the seeding mix should contain some dormant seed to insure subsequent stand establishment if the first stand is diminished by unfavorable environmental conditions. When using native legumes, such as Illinois bundleflower and western indigo, the land manager might plant a mixture of scarified and untreated seed. The data suggested that Illinois bundleflower seed stored longer than 1 year at $16^{\circ} \mathrm{C}$ and $40 \%$ relative humidity should be scarified, since hard seededness apparently increases with the length of storage. Scarification is recommended for western indigo seed stored for 1 or 2 years under the same conditions, but not for seed stored for 4 years. Four-year-old seed has a relatively low hard seed content and provides a good 
mixture of readily germinable seed for initial stand establishment and dormant seed for subsequent stand establishment. The data also indicate that scarification treatments increase the rates of germination of these species, which should improve the potential for stand establishment under transiently favorable environmental conditions.

\section{Literature Cited}

Berkat, O., and D.D. Briske. 1982. Water potential evaluation of three germination substrates utilizing polyethylene glycol 20,000. Agron. J. 74:518-521.

Copeland, L.0. 1976. Principles of seed science and technology. Burgess Publ. Co., Minneapolis, Minn.

Crosier, W.E. (ed.). 1970. Rules for testing seeds. Proc. of Ass. Off. Seed Analysts 60(2).

Ellis, R.H., and E.H. Roberts. 1978. Towards a rational basis for testing seed quality, p. 605-636. In: P.D. Hebblethwaite (ed), Seed Production. Butterworths, London.

Grabe, D.F. (ed.). 1970. Tetrazolium testing handbook for agricultural seeds. Contribution No. 29 to the handbook on seed testing. Ass. Off. Seed Analysts. Lansing, Mich.

Graham, E.H. 1941. Legumes for erosion control and wildlife. USDA Pub. No. 412, U.S. Gov. Printing Office, Washington, D.C.

Grime, J.P. 1979. Plant strategies and vegetation processes. John Wiley and Sons, N.Y.

Hanelt, P. 1977. Ecological and taxonomic aspects of the longevity of seeds. Biologische Rundschau 15:81-91.

Hillel, D. 1972. Soil moisture and seed germination, p. 65-89. In: T.T. Kozlowski (ed), Water Deficits and Plant Growth. Vol. III. Plant responses and control of water balance. Academic Press, N.Y.

\section{Department Head Department of Range Science Utah State University Logan, Utah}

We are searching for a person with commitment to, and an understanding of, quality in academic institutions; a person with a vision of program development that reflects the collective goals of the faculty; a person with a vision of the role of rangelands in contributing to society's future needs and the ability and imagination to lead teaching, research and extension programs to bring this version to reality; a person with an understanding of the tripartite mission of a range science department in a land grant university.

Specific qualifications include:

Earned doctorate in range science or related field.

Experience as a faculty member in an academic institution.

Awareness of natural resource issues and dedication to solv-

ing. range management problems.

Demonstrated scholarship resulting from an active research program.

University teaching experience, and an understanding of, and commitment to, teaching excellence in both undergraduate and graduate programs.

Extension experience and an understanding of, and commitment to, excellence in the mission and function of extension programs.

Administrative skills: ability demonstrated by successful experience dealing with people and fiscal affairs.

Interested persons should submit a letter of application, personal vita, and names of four references to Dr. Martyn Caldwell, Search Subcommittee Chairman, Range Science Dept. UMC 52, Utah State University, Logan, Utah 84322. Deadline for applications is December 16,1985 , or until position is filled.

\section{AA/EOE}

Kissock, D.C., and M.R. Haferkamp. 1983. Presowing seed treatment and temperature effects on germination of Engelmannia pinnatifida and Indigofera miniata var. leptosepala. J. Range Manage. 36:94-97.

Koller, D. 1972. Environmental control of seed germination, p. 1-101. In. T.T. Kozlowski (ed), Seed Biology. Vol. II. Germination control, metabolism, and pathology. Academic Press, N.Y.

Latting, J. 1961. The biology of Desmanthus illinoensis. Ecology 42:487-493.

Mayer, A.M., and A. Poljakoff-Mayber. 1982. The germination of seeds. 3rd Ed. Pergamon Press, N.Y.

McDonough, W.T. 1977. Seed physiology, p. 155-184. In: R.E. Sosebee (ed), Rangeland Plant Physiology. Soc. Range Manage., Denver, Colo.

Ray, A.A. (ed). 1982. SAS user's guide: statistics. SAS Institute, Cary, N.C.

Rechenthin, C.A. 1972. Native flowers of Texas. USDA, Soil Conserv. Serv., Temple, Tex.

Sims, P.L., C.H. Herbel, R.F. Barnes, and SEA-AR Rangeland Scientists in the Southern Great Plains. 1980. SEA - AR range research assessment: Southern Great Plains. Agr. Res., Sci. Educ., Admin., USDA, Washington, D.C.

Soil Conservation Service. 1980. Highlights of the Knox City Plant Materials Center, USDA, Soil Conserv. Serv., Knox City, Tex.

Soil Conservation Service. 1983. Notice of release of Sabine Illinois bundleflower. USDA, Soil Conserv. Serv., Temple, Tex.

Steele, R.G.D., and J.H. Torrie. 1960. Principles and procedures of statistics. McGraw-Hill, Inc., N.Y.

Stevens, R., K.R. Jorgensen, and J.N. Davis. 1981. Viability of seed from thirty-two shrub and forb species through fifteen years of warehouse storage. Great Basin Natur. 41:274-277.

Thompson, P.A. 1981. Ecological aspects of germination, p. 9-42. In: J.R. Thompson (ed), Advances in Research and Technology of Seeds. Centre for Agr. Pub. and Documentation, Wageningen, the Netherlands.

Wasser, C.H. 1982. Ecology and culture of selected species useful in revegetating disturbed lands in the West. FWS/OBS-82/56, U.S. Dep. Int., Fish Wildl. Serv., Washington, D.C.

\section{GRADUATE RESEARCH ASSISTANT, PhD LEVEL}

Responsibilities: Quantify animal-plant interactions, animal foraging behavior in conjunction with multidisciplinary grazing system research. Minimum qualifications: B.S., M.S. degree in Range Science, Animal Science or related field. Experience with microcomputers helpful. Location: Department of Animal, Dairy, and Veterinary Sciences. Deadline: February 1, 1986. Contact:

Dr. Richard L. Senft

Department of ADVS

Utah State University

Logan, Utah 84322-4815

Phone (801) 750-2158

An Affirmative Action/Equal Opportunity Employer

ASSISTANT PROFESSOR/RANGE SCIENCE. Twelve-month, $100 \%$ research, tenure-track position with competitive salary. Position is located at the Fort Hays Branch, Kansas Agricultural Experiment Station, Kansas State University. Individual will develop a research program emphasizing efficient conversion of grazed native and planted forages to livestock product. Program breadth allows opportunity for both fundamental and applied studies and participation in interdisciplinary research projects. A Ph.D. with primary emphasis in range science and a strong appreciation for and understanding of ruminant animal nutrition, growth and reproduction is required. Send letter or application, resume, transcripts, and have three letters of reference sent by 1 December 1985 to Dr. Patrick I. Coyne, Head; Ft. Hays Experiment Station; Hays, KS 67601. An Equal Opportunity Employer. 